\title{
MEMBANGUN AKTUALIASI PEMBELAJARAN DENGAN TEORI KECERDASAN MAJEMUK
}

\section{Abstraksi}

Kecerdasan atau intelejensi seseorang ada atau dibawa sejak dia dilahirkan. Akan tetapi perkembangan intelegensi itu didapatkan seseorang seiring perkembangannya dalam kehidupan. Inteligensi atau kecerdasan selama ini sering diartikan sebagai kemampuan memahami sesuatu dan kemampuan berpendapat, di mana semakin cerdas seseorang maka semakin cepat ia memahami suatu permasalahan dan semakin cepat pula mengambil langkah penyelesaiannya Dalam hal ini, kecerdasan dipahami sebagai kemampuan intelektual yang lebih menekankan logika dalam memecahkan masalah. Kecerdasan seseorang biasanya diukur melalui tes Intelligence Quotient (IQ) Pada tulisanini dipaparkan Tentang teori belajar pada segmentasi teori kecerdasan majmuk yang di lontarkan oleh Howard Gardner untuk menunjukkan bahwa pada dasarnya manusia itu memilik banyak kecerdasan, tidak hanya sebatas IQ seperti yang dikenal selama ini. Menurut Gardner, sedikitnya ada sembilan kecerdasan yang dimiliki oleh manusia yaitu kecerdasan linguistik, matematis-logis, ruang-visual (spasial), kinestetikbadani, musikal, interpersonal, dan intrapersonal, naturalis dan kecerdasan eksistensial.

Keyword: intrapersonal, naturalis Intelligence Quotient Multiple Intelligences

Holili, M.Pd.I

Praktisi Pendidikan, Ketua MGMP PAI Bangkalan, Guru SMPN 2 Galis

Holili007@gmail.co.id 


\section{A. Latar Belakang Munculnya Teori Kecerdasan Majemuk}

Menurut Agus Efendi, ketika mengantarkan edisi ke-10 dari Frames of Mind (1983), Gardner menegaskan bahwa sembari menulis Frames of Mind, ia memandang karya tersebut sebagai kontribusinya terhadap disiplin psikologi perkembangan yang digelutinya. Dengan karya tersebut, Gardner hendak memperluas konsepsi kecerdasan, dari hanya menyangkut the result of paper and pencil test, menjadi pengertian yang lebih luas yang menyangkut pengetahuan tentang otak manusia dan kepekaannya terhadap ragam budayanya (sensitivity to the diversity of human cultures) . ${ }^{1}$

Namun demikian, terbitnya buku tersebut, menurut Joy A. Palmer, justru menempatkan dia dalam percaturan teori dan praktik pendidikan di Amerika Serikat serta membuatnya terkenal di seluruh dunia. ${ }^{2}$ Oleh karena mendapat sambutan dari dunia pendidikan, maka dalam karya selanjutnya mengenai kecerdasan majemuk, seperti Multiple Intelligences: The Theory in Practice, Multiple Intelligences: New Horison, dan sebagainya, menurut Agus Efendi, Gardner banyak memasukkan wacana-wacana pendidikan kontemporer. Dengan demikian, karya-karya sesudah Frames of Mind, lebih dijadikan sebagai penyerta dan penyempurnaan bagi karya tersebut. ${ }^{3}$ Terlepas dari itu semua, dalam bukunya Frames of Mind, Gardner menjelaskan empat hal terkait dengan latar belakang munculnya teori kecerdasan majemuk, yaitu The Idea of Multiple Intelligences (ide mengenai kecerdasan majemuk), Intelligences: Earlier Views (pandangan awal mengenai kecerdasan), Biological Foundations of Intelligences (fondasi biologis kecerdasan), dan The Definiton of Intelligence (definisikecerdasan). ${ }^{4}$

Mengawali penjelasan tentang ide mengenai kecerdasan majemuk, Gardner memberikan ilustrasi sebagai berikut:

\footnotetext{
${ }^{1}$ Agus Efendi, Revolusi Kecerdasan Abad 21: Kritik MI, EI, SQ, AQ, dan Successful Intelligence atas IQ, (Bandung: Alfabeta, 2005), hlm. 136-137

${ }^{2}$ Joy A. Palmer, 50 Pemikir Paling Berpengaruh Terhadap Dunia Pendidikan Modern, terj. Farid Assifa, (Yogyakarta, IRCiSoD, 2006), hlm. 482-483.

${ }^{3}$ Agus Efendi, Revolusi Kecerdasan Abad 21..., hlm. 137

${ }^{4}$ Howard Gardner, Frames of Mind: The Theory of Multiple Intelligences, (New York: Basic Books, 1983), hlm. 3-7
} 
"A Young Girl spends an hour whit an examiner. She is asked a number of questions that probe her store of information (who discovered America? What does the stomach do?), her arithmetic skills (at eight cent each, how much will three candy bars cost?), her ability to remember a series of numbers $(5,1,7,4,2,3,8)$, her capacity to grasp the similarity between two elements (elbow and knee, mountain and lake). She may also be asked to carry out certain other tasks-for example, solving a maze or arranging a group of pictures in such a way that they relate a complete story. Some time afterward, the examiner scores the responses and comes up with a single number-the girl's intelligence quotient, or IQ. "',

Berdasarkan ilustrasi tersebut dipahami bahwa kecerdasan seringkali hanya dihargai dan dinilai dengan tes IQ melalui ujian tertulis atau lisan yang menekankan pada kemampuan menghafal, mengingat, dan menceritakan suatu peristiwa, menghitung, atau memecahkan suatu teka-teki yang mengarah pada kemampuan linguistik dan matematis logis. Bahkan, kecerdasan tersebut hanya dihargai dengan skor-skor yang merupakan hasil penjumlahan dari seluruh jawaban yang dianggap mampu dijawab dengan benar oleh seseorang. Dengan demikian, belum ada anggapan bahwa kemampuan-kemampuan lain yang dimiliki manusia itu juga kecerdasan. Penilaian tersebut, menurut Gardner, akan memberikan pengaruh yang cukup besar bagi masa depan seseorang, mempengaruhi penilaian guru terhadapnya dan menentukan sifat elijibilitas untuk hak-hak istimewanya. Namun menurut Gardner, penilaian tersebut tidak semuanya

\footnotetext{
${ }^{5}$ Ibid., hlm. 3. Adapun terjemahan bebasnya adalah seorang perempuan muda menghabiskan waktu satu jam bersama seorang penguji. Dia ditanya sejumlah pertanyaan yang menyelidiki informasi yang dipahaminya dalam bidang sejarah (siapa yang menemukan Amerika? Apa yang dikerjakan oleh perut?), kemampuan aritmatikanya (jika satu batang permen seharga delapan sen, berapa harga tiga batang permen?), kemampuannya untuk mengingat rangkaian nomor-nomor $(5,1,7,4,2,3,8)$, kemampuannya untuk memahami kesamaan antara dua elemen (sikudan lutut, gunung dan danau). Dia juga mungkin diminta untuk mengerjakan tugas-tugas yang lain-seperti memecahkan sebuah jaringan jalan yang ruwet atau menyusun sekelompok gambar-gambar sedemikian rupa sehingga gambar-gambar tersebut menjadi sebuah cerita yang sempurna. Kadang-kadang setelah itu, penguji memberikan skor terhadap jawabanjawaban tadi dan sampai pada satu angka -kecerdasan inteligensi atau IQ perempuan tersebut
} 
salah, dalam artian bahwa skor yang diperoleh melalui tes inteligensi tersebut mampu memprediksi keberhasilan seseorang di sekolah. Namun demikian, hasil tes tersebut tidak bisa meramalkan kesuksesan hidup seseorang di kemudian hari. ${ }^{6}$

Peristiwa-peristiwa seperti itu, tulis Gardner, terjadi ribuan kali setiap harinya di seluruh dunia walaupun dengan berbagai versi yang disesuaikan dengan usia dan setting budayanya. Kebanyakan tes tersebut dilakukan dengan menggunakan kertas dan pensil daripada dilakukan secara langsung bersama seorang penguji. ${ }^{7}$ Oleh karena itu, menurut Gardner sebagaimana dikutip oleh Agus Efendi, banyak peneliti kecerdasan yang tidak puas dengan keadaan seperti itu. Bagi mereka, pasti ada banyak kecerdasan daripada sekedar jawaban pendek terhadap pertanyaan singkat -jawaban yang menduga keberhasilan akademis. Namun, cara ini justru terus diulang secara universal untuk menduga masa depan seseorang, bahkan hingga saat ini. ${ }^{8}$

Dengan demikian, tidak ada penghargaan yang memadai untuk kemampuan-kemampuan lain yang dimiliki manusia bahkan sekedar untuk menganggap kemampuan-kemampuan tersebut sebagai kecerdasan. Sehingga orang-orang yang memiliki kemampuankemampuan luar biasa dalam bidang lain, seperti para navigator, atlet, dan ahli komputer, tidak dianggap sebagai orang-orang yang cerdas karena lemahnya kemampuan mereka dalam bidang linguistik dan matematis-logis.

Selanjutnya, menurut Gardner, sebuah refleksi menyatakan bahwa setiap individu akan mencapai level kemampuan yang tinggi dalam sebuah bidang tertentu. Oleh karena itu, sudah seharusnya kecerdasan memiliki definisi istilah yang lebih layak, karena jelas bahwa metode penaksiran kecerdasan melalui tes-tes IQ tidak cukup baik untuk menghargai potensi-potensi atau prestasi-prestasi seseorang. Dengan demikian, problemnya terletak pada teknologi pengujiannya, sehingga perlu adanya perluasan dan reformulasi pandangan mengenai kecerdasan manusia sampai ditemukan cara yang lebih tepat untuk

\footnotetext{
${ }^{6}$ Ibid., hlm. 3

${ }^{7}$ Ibid., hlm. 4.

${ }^{8}$ Agus Efendi, Revolusi Kecerdasan Abad 21..., hlm. 138.
} 
menaksir kecerdasan tersebut dan cara yang lebih efektif untuk mendidiknya.

Bahkan, banyak orang yang terlibat dalam dunia pendidikan memiliki kesimpulan yang sama bahwa ada program-program baru yang menarik yang mencoba untuk mengembangkan kecerdasan manusia untuk seluruh budaya dan melatih individu-individu tentang kemampuan-kemampuan umum, seperti "Pembelajaran Antisipatori," untuk membantu individu-individu merealisasikan potensi-potensi mereka. ${ }^{9}$

Selanjutnya, menurut Gardner, kehadiran teori kecerdasan majemuk ini adalah untuk menentang pandangan-pandangan klasik mengenai kecerdasan yang secara eksplisit atau implisit telah menyihir manusia melalui psikologi dan teks-teks pendidikan. Kemudian untuk mempermudah identifikasi sisi-sisi baru dari teori ini, Gardner mencoba menunjukkan beberapa fakta mengenai pandangan-pandangan tradisional tentang kecerdasan. Menurut Gardner, lebih dari dua ribu tahun, minimal sejak bangkitnya negara-kota Yunani, terdapat serangkaian ide yang mendominasi diskusi-diskusi mengenai kondisi manusia dalam suatu peradaban. Ide-ide ini menekankan pada eksistensi dan pentingnya kekuatan mental, yaitu kemampuan manusia yang kemudian diungkapkan dengan berbagai terma, seperti rasionalitas, inteligensi, atau penyebaran pikiran. Dalam pencariannya mengenai esensi manusia,

Gardner melakukan penelitian terhadap kemampuan-kemampuan khusus dari beberapa tokoh, seperti Plato, ahli-ahli kitab terpelajar di biara, atau ilmuwan di laboratorium. Menurut Gardner, mereka semua adalah orang-orang yang mampu menggunakan kekuatan-kekuatan mental mereka dalam dunia nyata. Socrates mengatakan "kenali dirimu," dan Aristoteles mengatakan "seluruh manusia secara alamiah memiliki hasrat untuk mengetahui," sementara itu Descartes mengatakan "Aku berpikir: oleh karena itu, aku ada."Semua pendapat tersebut, menurut Gardner, memberikan inskripsi yang membingkai seluruh peradaban. ${ }^{10}$

\footnotetext{
${ }^{9}$ Howard Gardner, Frames of Mind..., hlm. 4-5

${ }^{10}$ Ibid., hlm. 5-6
} 
Kemudian pada abad kegelapan, antara abad klasik dan renaisans, persoalan kecerdasan ini jarang ditentang. Mengenai awal abad pertengahan ini, St. Augustine sebagaimana dikutip Howard Gardner menegaskan bahwa:

"The prime author and mover of the universe is intelligence. Therefore, the final cause of the universe must be the good of the intelligence and that is truth.... Of all human pursuit of wisdom is the most perfect, the most sublime, the most useful, and the most agreeable. The most perfect, be cause in so far as aman gives himself up to the pursuit of wisdom, to that extent the enjoys already some portion of true happiness. "' ${ }_{l l}$

Dari pernyataan tersebut, jelaslah bahwa kecerdasan memiliki posisi yang sangat fundamental dalam peradaban umat manusia. Oleh karena itu,kecerdasan harus dijunjung tinggi dan harus mampu membawa manusia pada hakikat kebenaran dan kearifan. Karena dua hal yang mendasari kecerdasan itulah yang menyebabkan kecerdasan memiliki kedudukan yang tinggi dalam suatu peradaban. Kemudian pada puncak abad pertengahan, Dante sebagaimana dikutip oleh Howard Gardner mengajukan pandangannya tentang "fungsi yang tepat bagi ras manusia, akibat dari semua itu adalah untuk mengaktualisasikan seluruh kapasitas kecerdasan secara kontinyu, terutama dalam spekulasi dan aksi .

Terkait dengan kecerdasan, seperti yang dikutip oleh Agus Efendi, Gardner mengungkapkan bahwa ada dua pandangan yang berbeda mengenai kecerdasan. Pertama, kaum hedgehog yang meyakini bahwa kecerdasan itu adalah sebuah potongan, tunggal, dan statis. Bagi mereka setiap manusia dilahirkan dengan sejumlah kecerdasan tertentu yang disebut dengan IQ. Kedua, kaum foxes yang mengagungkan

\footnotetext{
${ }^{11}$ Ibid., hlm. 6. Terjemahan bebasnya adalah pengarang dan penggerak utama alamsemesta itu adalah kecerdasan. Oleh karena itu, sebab akhir alam semesta haruslah baiknya kecerdasan dan itu merupakan suatu kebenaran.... Seluruh manusia itu mencari, mencari kearifan adalah yang paling sempurna, paling luhur, paling berguna, dan paling dapat disepakati. Paling sempurna, karena sejauh ini seperti seorang lelaki memberikan dirinya sendiri sesuai dengan pencarian kearifan, sampai pada tahap tersebut dia sudah menikmati sebagian kebahagiaan yang sejati.
} 
sejumlah fungsi berbeda atau bagian-bagian mental. Bagi mereka kecerdasan itu bersifat dinamis dan bisa berkembang. Selain itu, Gardner juga menyebutkan bahwa para pemikir abad pertengahan memiliki trivium yang mencakup tata bahasa, logika, dan retorika, serta memiliki quadrivium yang mencakup matematika, geometri, astronomi, dan musik. ${ }^{12}$

\section{B. Macam-Macam Kecerdasan Majemuk}

Berdasarkan penelitian akhirnya Gardner dalam bukunya Frames of Mind (1983) mengemukakan tentang teori kecerdasan majemuk atau multiple intelegence (MI). ${ }^{13}$ Kecerdasan majemuk terdiri atas:

1. Kecerdasan Linguistik (bahasa)

Kemampuan membaca, menulis dan berkomunikasi dengan katakata atau bahasa seperti penulis, jurnalis, penyair, orator dan pelawak. Contoh: Charles Dickens, Abraham Lincoln, T. S Eliot, Sir Winston Churchill.

2. Kecerdasan Logis-Matematis

Kemampuan berpikir (menalar) dan menghitung, berpikir logis dan sistematis seperti ilmuwan, ekonom, akuntan, detektif dan para profesi hukum. Contoh yang terkenal Albert Enstein.

3. Kecerdasan Visual-Spasial

Kemampuan berpikir menggunakan gambar, memvisualisasikan hasil masa depan. Ini jenis ketrampilan yang dikembangkan oleh arsitek, pemahat, pelaut, penjelajah dan fotografer. Contoh: Picasso, Frank Lloyd Wright, Colombus.

4. Kecerdasan Musikal

Kemampuan mengubah atau mencipta musik, dapat bernyanyi dengan baik, atau memahami dan mengapresiasi musik, serta menjaga ritme. Hal ini biasanya menempel pada para musisi, komposer dan perekayasa rekaman. Contoh: Mozart, David Foster.

5. Kecerdasan Kinestetik-Tubuh

Kemampuan menggunakan tubuh secara terampil untuk memecahkan masalah, menciptakan produk atau mengemukakan gagasan dan emosi seperti atlet, penari, aktor, ahli bedah, atau dalam

\footnotetext{
${ }^{12}$ Agus Efendi, Revolusi Kecerdasan Abad 21..., hlm. 139.

${ }^{13}$ Howard Gardner, Frames of Mind..., hlm. 36-42
} 
bidang kontruksi atau bangunan. Contoh: Charlie Chaplin, Michael Jordan.

6. Kecerdasan Interpersonal (sosial)

Kemampuan bekerja secara efektif dengan orang lain, berhubungan dengan orang lain dan memperlihatkan empati dan pengertian, memperhatikan motivatsi dan tujuan mereka. Pemilik kecerdasan ini biasanya adalah guru yang baik, fasilisator, penyembuh, politisi, pemuka agama. Contoh: Gandhi, Ronald Reagan, Mother Teresa, Oprah Winfrey.

7. Kecerdasan Intrapersonal

Kemampuan menganalisa-diri dan merenungkan diri-mampu merenung dalam kesunyian dan menilai prestasi seseorang, meninjau perilaku seseorang dan perasaan-perasaan terdalamnya, membuat rencana dan menyusun tujuan yang hendak dicapai, mengenal benar diri sendiri. Kecerdasan ini dimiliki oleh filsuf, penyuluh, pembimbing, contoh: Eleanor Roosevelt, Plato.

Pada tahun 1996, Gardner memutuskan menambah jenis kecerdasan kedelapan yaitu:

8. Kecerdasan Naturalis

Kemampuan mengenal flora dan fauna, melakukan pemilihan runtut dalam dunia kealaman dan menggunakan kemampuan ini secara produktif, misalnya berburu, bertani atau melakukan penelitian biologi. Contoh: Charles Darwin.

9. Kecerdasan Eksistensial ( Existential Intelligence )

Kecerdasan eksistensial, menurut Howard Gardner sebagaimana dikutip oleh Thomas Armstrong, adalah minat pada masalah-masalah pokok kehidupan. Kecerdasan ini mencakup kemampuan menempatkan diri dalam hubungan dengan jangkauan kosmos yang terjauh -yang tidak terhingga besarnya dan tidak terhingga kecilnya- dan kemampuan lain yang terkait, yakni menempatkan diri dalam hubungan dengan berbagai aspek eksistensial manusia, misalnya makna hidup, arti kematian, nasib dunia fisik dan psikologis, serta pengalaman mendalam seperti cinta pada sesama atau keterlibatan total dalam karya seni. ${ }^{14}$

\section{Implikasi Kecerdasan Majemuk dalam Pendidikan}

${ }^{14}$ Thomas Armstrong, Sekolah Para..., hlm 25 
Seperti yang telah diungkapkan, kecerdasan majemuk itu pada dasarnya ada dalam diri setiap orang dan bisa dikembangkan melalui pendidikan. Dalam upaya mengembangkan sembilan kecerdasan tersebut, menurut Baharuddin dan Esa Nur Wahyuni, ada beberapa prinsip yang bisa dijadikan pedoman, antara lain: ${ }^{15}$

1. Pendidikan harus memperhatikan semua kemampuan intelektual. Oleh karena itu, dalam proses pembelajaran guru tidak boleh terpaku hanya pada satu jenis kemampuan saja, karena satu jenis kemampuan saja tidak cukup untuk menjawab persoalan-persoalan manusia secara menyeluruh.

2. Pendidikan seharusnya individual. Setiap karakteristik yang dimiliki siswa harus mendapat perhatian dalam proses pembelajaran. Mengajar hanya dengan materi, cara, dan waktu yang sama bagi siswa yang memiliki kemampuan tertentu, tentunya tidak menguntungkan bagi siswa lain yang memiliki kecerdasan yang berbeda.

3. Pendidikan harus dapat memotivasi siswa untuk menentukan tujuan dan program belajar. Proses pembelajaran yang baik, menurut mereka adalah memberikan kebebasan kepada siswa untuk menentukan sendiri cara belajarnya sesuai dengan kemampuan yang dimilikinya, siswa diberi kebebasan untuk mengevaluasi sendiri hasil belajar mereka.

4. Sekolah memberikan fasilitas kepada siswa untuk mengembangkan kecerdasan majemuk yang mereka miliki, misalnya siswa membutuhkan peralatan olahraga, seni, atau musik untuk mengembangkan kecerdasan mereka, maka sekolah harus menyediakannya.

5. Evaluasi proses pembelajaran harus lebih kontekstual dan tidak hanya terbatas pada tes tertulis. Evaluasi kontekstual lebih menekankan pada penilaian performa siswa dalam proses belajar, apakah sesuai dengan kriteria yang diharapkan atau tidak.

6. Proses pembelajaran sebaiknya tidak dibatasi hanya dalam gedung sekolah. Konsep kecerdasan majemuk ini memungkinkan proses

15 Baharuddin dan Nur Wahyuni, Teori Belajar dan Pembelajaran, Yogyakarta: Ar-Ruzz Media, 2007.hlm. 153-154 
pembelajaran terjadi di luar gedung sekolah, seperti melalui masyarakat, kegiatan ekstra, atau kontak dengan orang lain.

Berkenaan dengan implikasi teori kecerdasan majemuk dalam pendidikan, dapat terbagi atas:

1. Bagi penilaian

a. Menilai kecerdasan siswa

Untuk mengetahui kecenderungan arah kecerdasan siswa, menurut Thomas Armstrong sebagaimana dikutip oleh Asri Budiningsih, dapat dinilai melalui indikator-indikator tertentu. Misalnya, apa yang dikerjakan siswa ketika mereka mempunyai waktu luang. Selain itu, untuk memantau kecenderungan perkembangan kecerdasan siswa di kelas, setiap guru dapat menggunakan catatan-catatan kecil praktis ( checklist), dokumen berupa foto, rekaman-rekaman lain yang berhubungan dengan aktivitas siswa, dan catatan-catatan di sekolah yang berhubungan dengan peringkat nilai semua mata pelajaran. Selain itu, penilaian juga dapat dilakukan dengan memberdayakan siswa sendiri, dalam artian bahwa checklist yang digunakan untuk menilai kecerdasan siswa tidak diisi oleh guru namun pengisian dilakukan oleh para siswa. Jadi, siswa yang satu bisa menilai kecerdasan temannya yang lain. Selain itu, dia juga diberi kesempatan untuk menilai dirinya sendiri. ${ }^{16}$

b. Menilai prestasi siswa melalui teori kecerdasan majemuk

Menurut teori kecerdasan majemuk, sebagaimana diungkapkan oleh Thomas Armstrong, ada banyak cara yang digunakan untuk menilai prestasi (mengevaluasi) siswa, antara lain melalui observasi, pendokumentasian hasil karya siswa, penilaian proyek, penilaian melalui delapan cara, penilaian dalam konteks yang sesuai, dan portofolio. Namun yang paling penting untuk diperhatikan dalam penilaian prestasi siswa dalam teori ini, menurut Armstrong, adalah penilaian hendaknya tidak bergantung pada tes standar atau tes yang didasarkan pada norma formal, tetapi lebih banyak didasarkan pada penilaian autentik.

${ }^{16}$ Asri Budiningsih, Belajar dan Pembelajaran. PT. Rineka Cipta, Jakarta, 2012, hlm. 120121 
Selain itu, prestasi yang diperoleh siswa tidak bergantung pada siswa yang lain, namun prestasinya dilihat dari perbandingan antara prestasi yang diperoleh siswa pada waktu sebelumnya dengan prestasinya sekarang. ${ }^{17}$

2. Bagi penggunaan strategi

Implikasi teori kecerdasan majemuk dalam pendidikan, menurut Asri Budiningsih, paling nampak terlihat pada strategi yang digunakan dalam proses pembelajaran. Guru perlu menggunakan strategi umum maupun khusus dalam pembelajaran untuk mengembangkan seluruh kecerdasan siswa secara optimal, karena setiap siswa memiliki kecenderungan yang berbeda dalam perkembangan kecerdasan majemuknya. Oleh karena itu, tidak ada satu pendekatan atau strategi pun yang cocok digunakan bagi semua siswa. ${ }^{18}$ Namun demikian, menurut Paul Suparno, dengan adanya perbedaan kecerdasan dari setiap siswa itulah, maka pendekatan personal dalam pendidikan perlu dilakukan. ${ }^{19}$

3. Bagi pengembangan kurikulum

Mengenai implikasi teori kecerdasan majemuk dalam pengembangan kurikulum, dalam bukunya Sekolah Para Juara, Thomas Armstrong mengatakan bahwa pendekatan terbaik dalam pengembangan kurikulum adalah dengan memikirkan cara menerjemahkan materi-materi yang akan diajarkan dari satu kecerdasan kepada kecerdasan yang lain. ${ }^{20}$ Dengan demikian, apa pun materinya sebenarnya bisa disampaikan kepada peserta didik asalkan bisa diterjemahkan ke dalam sistem-sistem simbol dari semua kecerdasan di atas. Sementara itu, terkait dengan implikasi teori kecerdasan majemuk terhadap kurikulum (semua pengalaman yang direncanakan untuk dialami siswa dalam proses pendidikan sejak awal), Paul Suparno menyatakan bahwa keberadaan teori kecerdasan majemuk telah memberikan pengaruh yang sangat besar

${ }^{17}$ Armstrong, Thomas, 7 Kinds of Smart: Menemukan dan Meningkatkan Kecerdasan Anda Berdasarkan Teori Multiple Intelligences, terj. T. Hermaya Jakarta: , Gramedia Pustaka Utama, 2002. hlm. 177-199

${ }^{18}$ Asri Budiningsih, Belajar dan..., hlm. 120

${ }^{19}$ Paul Suparno, Teori Inteligensi..., hlm. 52

${ }^{20}$ Thomas Armstrong, Sekolah Para..., hlm. 88 
terhadap pemilihan materi pelajaran, dalam hal ini materi pelajaran dibuat berdasarkan topik-topik tematik, bukan berdasarkan urutan daftar bab seperti model kurikulum klasik. Topik-topik tematik ini merupakan gabungan dari materi yang ditentukan oleh pemerintah lokal dan minat serta kesenangan siswa.

4. Bagi penataan lingkungan kelas

Menurut Thomas Armstrong, penataan ruang kelas yang baik menurut teori kecerdasan majemuk, bukanlah dengan penataan yang kaku, di mana siswa duduk di balik meja yang berbaris rapi ke depan, ke arah guru yang duduk di balik meja besar sambil mengoreksi pekerjaan siswa atau berdiri di samping papan tulis menguraikan pelajaran kepada siswa. Namun, lingkungan belajar yang digunakan dalam proses pembelajaran menurut teori ini lebih menekankan pada adanya faktor-faktor ekologis sesuai dengan masing-masing kecerdasan. Contohnya, poster atau kutipan-kutipan di dinding untuk kecerdasan linguistik, fleksibilitas tatanan meja, kursi, pajangan kelas, warna ruangan, dan jenis penerangan untuk kecerdasan spasial, serta penggunaan musik latar untuk kecerdasan musikal.

Selain faktor ekologis, teori kecerdasan majemuk menekankan adanya pusat-pusat atau pojok-pojok belajar untuk masing-masing kecerdasan yang disusun sedemikian rupa sehingga bisa mengaktifkan potensi-potensi belajar siswa yang beragam. Dengan adanya pusat-pusat atau pojok-pojok belajar tersebut, maka diharapkan siswa bisa terlibat dalam pengalaman belajar secara aktif serta memperoleh penekanan pada kecerdasannya yang paling dominan di satu pihak dan pengembangan kecerdasannya yang lain yang kurang berkembang di pihak lain. ${ }^{21}$

5. Bagi guru

Guru, menurut Paul Suparno, selama ini cenderung mengajar hanya dengan menggunakan dua macam kecerdasan, yaitu kecerdasan linguistik dan matematis-logis, atau mengajar dengan menggunakan satu model yang sesuai dengan kecerdasannya sendiri. Hal ini mengakibatkan siswa-siswa yang tidak menonjol dalam

${ }^{21}$ Thomas Armstrong, Sekolah Para..., hlm. 135-149 
kecerdasan-kecerdasan tersebut cenderung merasa terasing dan tidak pernah diajarkan oleh gurunya. ${ }^{22}$

Hadirnya teori kecerdasan majemuk ini, menurut Gardner sebagaimana dikutip oleh Paul Suparno, mencoba membantu guruguru tersebut untuk mengubah cara mengajar mereka, yaitu menggunakan kecerdasan majemuk yang lebih bervariasi dan disesuaikan dengan kecerdasan siswa. ${ }^{23}$ Oleh karena itu, berdasarkan teori kecerdasan majemuk, guru sebagai seorang pengajar sekaligus pendidik harus mengerti kecerdasan siswasiswanya, mengembangkan model mengajar dengan berbagai kecerdasan dan bukan hanya dengan kecerdasan yang menonjol pada dirinya, mengajar sesuai dengan kecerdasan siswanya, dan menggunakan berbagai model yang cocok dengan kecerdasan majemuk dalam proses evaluasi. ${ }^{24}$

6. Bagi siswa

Menurut Gardner, sebagaimana dikutip oleh Paul Suparno, siswa akan dapat belajar dengan baik apabila belajar sesuai dengan kecerdasannya yang paling dominan. Hal ini karena seringkali menyebabkan siswa merasa puas belajar hanya dengan menggunakan satu kecerdasannya. Akibatnya, seringkali siswa merasa kaget saat mengetahui bahwa dia bisa belajar dengan baik pula melalui kecerdasan-kecerdasan yang lain. ${ }^{25}$ Oleh karena itu, hadirnya teori kecerdasan majemuk ini, selain membantu siswa untuk memahami kecerdasan yang paling menonjol pada dirinya, juga membantu siswa untuk belajar dengan menggunakan kecerdasan-kecerdasannya yang lain yang kurang menonjol sehingga kecerdasan-kecerdasan tersebut juga bisa berkembang secara maksimal. ${ }^{26}$

7. Bagi pendidikan nilai

Menurut Paul Suparno, karena kecerdasan majemuk merupakan pengelompokan kemampuan dalam diri seseorang sehingga dapat

\footnotetext{
${ }^{22}$ Paul Suparno, Teori Inteligensi..., hlm. 14

23 Ibid., hlm. 55

${ }^{24}$ Ibid., hlm. 58

${ }^{25}$ Ibid., hlm. 58-59

26 Ibid., hlm. 59
} 
berfungsi secara maksimal, maka jelas akan mempengaruhi pula jika seorang guru mau menanamkan nilai pada siswa karena pendidikan nilaiyang diberikan akan lebih mudah diterima oleh siswa jika memperhatikan kecerdasan mereka. Misalnya, jika guru ingin menyampaikan nilai kejujuran, maka tidak harus selalu melalui cerita tentang kejujuran, tetapi bisa juga melalui kerja kelompok, permainan, pembahasan masalah, musik, olahraga, tari, dan sebagainya. $^{27}$ Dengan demikian, teori kecerdasan majemuk juga 232memiliki implikasi terhadap pendidikan nilai, sama seperti implikasinya terhadap pendidikan-pendidikan yang lain. Sementara itu, Gardner sendiri dalam bukunya Multiple Intelligences, selain membahas implikasi kecerdasan majemuk dari beberapa segi di atas, juga meninjau implikasi kecerdasan majemuk terhadap pendidikan dari segi pertumbuhan atau perkembangan alami dari kecerdasan itu sendiri. Pertumbuhan atau perkembangan kecerdasan ini memiliki peranan yang sangat penting dalam pengembangan kurikulum. ${ }^{28}$

Menurut Gardner, pertumbuhan alami dalam setiap kecerdasan dimulai dengan kemampuan membuat pola dasar, misalnya kemampuan untuk membedakan tinggi-rendahnya nada dalam kecerdasan musik atau memahami pengaturan tiga dimensi dalam kecerdasan ruang. Semua kemampuan tersebut muncul secara universal dan lebih mendominasi dalam tahun pertama kehidupan.

Selanjutnya, kecerdasan dipandang sekilas menggunakan lensa berbeda pada titik-titik perkembangan berurutan, di mana pada tahap perkembangan tersebut, kecerdasan dihadapi lewat sistem simbol. Pada saat ini anak-anak menunjukkan kemampuan dalam berbagai kecerdasan lewat pemahaman berbagai sistem simbol. Ketika kemajuan berkembang, masing-masing kecerdasan bersama-sama dengan sistem simbol tersebut diwakili dalam sistem penulisan. Akhirnya, selama akil baligh dan dewasa, kecerdasan dinyatakan lewat rentang pengajaran profesi dan hobi. Misalnya, kecerdasan ruang melewati peta mental dari balita, ke operasi simbolik yang diperlukan dalam menggambar dan sistem penulisan peta pada masa

27 Ibid., hlm. 63

${ }^{28}$ Howard Gardner, Multiple Intelligences (terj.)..., hlm. 50 
kanak-kanak, sampai peran dewasa dari navigator, pemain catur, dan ahli topologi. ${ }^{29}$

Oleh karena kecerdasan dimanifestasikan dengan cara yang berbeda di masing-masing tingkat perkembangan, maka pengembangan kurikulum dalam setiap tahap perkembangan juga berbeda. Dalam masa prasekolah dan tahun-tahun pertama sekolah dasar, menurut Gardner, perintah harus lebih menekankan peluang. Selama tahun-tahun ini anak-anak dapat menemukan sesuatu yang menarik dan kemampuan khas bagi mereka sendiri. Kemudian selama usia sekolah, pengajaran lebih menekankan pada penggunaan sistem simbol dan penguasaan sistem penulisan. Selain itu, pada tahap ini pengajaran praktis juga perlu dikembangkan secara maksimal. Akhirnya, dalam masa akil baligh, siswa lebih diarahkan pada penentuan dan pemilihan karir yang sesuai dengan bakat dan kecerdasan mereka.

Dengan demikian, menurut Gardner, implikasi tahap-tahap perkembangan kecerdasan tersebut dalam pendidikan dapat ditarik dari peran pendidikan dalam kaitannya dengan manifestasi perubahan kecerdasan sepanjang langkah-langkah perkembangan. Umpamanya, lingkungan yang desain sedemikian rupa untuk tahun-tahun pertama sekolah dasar, tentu kurang penting untuk akil baligh. Sebaliknya, pengajaran melalui sistem penulisan untuk para akil baligh, pada umumnya tidak cocok untuk anak-anak sekolah dasar. Hal ini terjadi, karena pada umumnya siswa mampu menguasai suatu pelajaran atau pelatihan, jika pelajaran dan pelatihan tersebut sesuai dengan tahap perkembangan mereka. ${ }^{30}$

Oleh karena itu, dalam menyampaikan suatu pelajaran, penggunaan strategi, penilaian, dan penataan ruang kelas dalam proses pendidikan harus senantiasa mengacu pada perkembangan siswa. Kegiatan pembelajaran yang dilakukan pada siswa sekolah dasar tentu berbeda dengan pembelajaran pada siswa SMP, SMA, maupun Perguruan Tinggi. Sementara itu, berdasarkan relevansi teori kecerdasan majemuk terhadap pendidikan di atas, ditinjau dari sudut teori belajar humanistik,

29 Ibid., hlm. 51-52

${ }^{30}$ Ibid., hlm. 53-54 
menurut Asri Budiningsih, dasar-dasar teori kecerdasan mejamuk sangat humanis. Karena teori ini sama halnya dengan teori humanistik, sangat menekankan pada positive regards, accepttence, awareness, dan selfworth, yang semuanya bermuara pada aktualisasi diri yang optimal. ${ }^{31}$

Namun demikian, menurut Asri Budiningsih, persoalannya adalah bagaimana menciptakan kondisi kelas yang mendukung bagi berkembangnya kecerdasan majemuk siswa, hal ini karena banyak guru yang mempersepsikan bahwa kelas yang baik itu adalah kelas yang diam, teratur, tertib, dan taat pada guru. Sementara itu, kelas yang ramai selalu dipersepsikan sebagai kelas yang negatif, tidak teratur, walaupun mungkin ramainya disebabkan karena siswa berdebat, berdiskusi, bereksplorasi, atau melakukan kegiatan-kegiatan positif lainnya. Padahal pendidikan dan pembelajaran yang mendasarkan pada kecerdasan majemuk, menurut Asri Budiningsih, membuka kesempatan pada para siswa untuk kritis dan mungkin tidak sependapat dengan guru karena siswa menemukan kebenaran-kebenaran lain dari kebenaran yang dipegang oleh para guru. Dengan demikian, perlu kiranya menciptakan suasana pembelajaran yang mendukung bagi perkembangan kecerdasan majemuk siswa. ${ }^{32}$

\section{Kesimpulan}

Setiap individu akan mencapai level kemampuan yang tinggi dalam sebuah bidang tertentu. Oleh karena itu, sudah seharusnya kecerdasan memiliki definisi istilah yang lebih layak, karena jelas bahwa metode penaksiran kecerdasan melalui tes-tes IQ tidak cukup baik untuk menghargai potensi-potensi atau prestasi-prestasi seseorang. Dengan demikian, problemnya terletak pada teknologi pengujiannya, sehingga perlu adanya perluasan dan reformulasi pandangan mengenai kecerdasan manusia sampai ditemukan cara yang lebih tepat untuk menaksir kecerdasan tersebut dan cara yang lebih efektif untuk mendidiknya

Howard Gardner menunjukkan bahwa pada dasarnya manusia itu memilik banyak kecerdasan, tidak hanya sebatas IQ seperti yang dikenal selama ini. Menurut Gardner, sedikitnya ada sembilan kecerdasan yang

${ }^{31}$ Asri Budiningsih, Belajar dan..., hlm. 124

${ }^{32}$ Ibid. 
Membangun Aktualisasi Pembelajaran dengan Teori Kecerdasan Majemuk

dimiliki oleh manusia yaitu kecerdasan linguistik, matematis-logis, ruang-visual (spasial), kinestetik-badani, musikal, interpersonal, dan intrapersonal, naturalis dan kecerdasan eksistensial.

Berkenaan dengan implikasi teori kecerdasan majemuk dalam pendidikan, dapat terbagi atas: Penilai, penggunaan strategi, pengembangan kurikulum, penataan lingkungan kelas, guru, siswa, pendidikan nilai. 
Holili

\section{DAFTAR PUSTAKA.}

Abdul Mujib dan Jusuf Mudzakir, 2002, Nuansa-nuansa Psikologi

Islam, Jakarta: RajaGrafindo Persada

Agus Efendi, 2005, Revolusi Kecerdasan Abad 21: Kritik MI, EI, SQ,

$A Q$, da Successful Intelligence atas IQ, Bandung: Alfabeta

Armstrong, Thomas, 2002, 7 Kinds of Smart: Menemukan dan Meningkatkan Kecerdasan Anda Berdasarkan Teori Multiple Intelligences, terj. T. Hermaya Jakarta: , Gramedia Pustaka Utama

Ary Ginanjar Agustian, 2005, ESQ: Rahasia Sukses Membangun Kecerdasan Emosi dan Spiritual, Jakarta: Arga

Asri Budiningsih, 2012, Belajar dan Pembelajaran. Jakarta PT. Rineka Cipta

Baharuddin dan Nur Wahyuni, 2007, Teori Belajar dan Pembelajaran, Yogyakarta: Ar-Ruzz Media

Danah Zohar dan Ian Marshall, 2007, SQ: Kecerdasan Spiritual, terj. Rahmani Astuti, dkk., Bandung: Mizan

Howard Gardner, 1983, Frames of Mind: The Theory of Multiple Intelligences, (New York: Basic Books , 2003, Multiple Intelligences: Kecerdasan Majemuk, Teori dalam Praktek, terj. Alexander Sindoro, Batam: Interaksara

Joy A. Palme, 2006r, 50 Pemikir Paling Berpengaruh Terhadap Dunia Pendidikan Modern, terj. Farid Assifa, Yogyakarta, IRCiSoD

May Lwin dkk , 2008., Ho w to Multiply Your Child's Intelligence: Ca ra Mengembangkan Berbagai Komponen Kecerdasan, terj.

Christine Sujana, Yogyak arta: Indeks

Mustaqim, 2004, Psikologi Pendidikan, Semarang: Fakultas Tarbiyah IAIN Walisongo 
Membangun Aktualisasi Pembelajaran dengan Teori Kecerdasan Majemuk

Sri Esti Wuryani Djiwandono, Psikologi Pendidikan, Jakarta: Grasindo, 2006

Steven J. Stein dan Howard, 2004 E. Book, EQ: 15 Prinsip Dasar Kecerdasan Emosional Meraih Sukses, terj. Trinanda Rainy Januarsari dan Yudhi Murtanto, Bandung: Kaifa

Thobroni, Muhammad dan Arif Budiman, 2011, Belajar dan Pembelajaran, Jogyakarta,: ArRuzz

Thomas R. Hoerr, 2007, Buku Kerja Multiple Intelligences, terj. Ary Nilandari, (Bandung : Mizan Pustaka 